\title{
Customer Satisfaction Analysis of Restaurant Industry: An Empirical Study on Rangpur City
}

\author{
Mst. Sadia Arefin ${ }^{1} *$ and Md. Rubel Hossain ${ }^{2}$ \\ ${ }^{1}$ Department of Business Administration, Gono Bishwabidyalay, Dhaka, Bangladesh; and ${ }^{2}$ Remittance Department, \\ International Division, Standard Bank Limited, Head Office, Motijheel, Dhaka, Bangladesh. \\ *Correspondence: sadiaarefingb@gmail.com (Mst. Sadia Arefin, Lecturer, Department of Business Administration, Gono \\ Bishwabidyalay, Dhaka, Bangladesh).
}

\begin{abstract}
At present, the service industry makes an important contribution to World's GDP, especially in Bangladesh. Customer satisfaction is one of the Catchwords of every service industry. The study is conducted to identify some key factors of customer satisfaction in the restaurant industry. In the Rangpur city area, 20 restaurants were selected to conduct the study. This research is based on an empirical study. Simple random sampling methods were used to select 120 customers. 5 points Likert scale and open-ended questions were used to prepare a questionnaire. This study tried to adjust customer's perceptions with service quality for the customers' satisfaction with the restaurant industry. Undesirable perceptions of customers were found concerning product and service quality, pricing policy, the value of the restaurant, and loyalty of those restaurants side by side concerning waiters' service and space convenience customers' perceptions were encouraging. Based on findings it was recommended that attention should be given to those critical issues to attract new customers and retain current customers.
\end{abstract}

Keywords: Customer satisfaction, Customer loyalty, Analysis, GDP, Empirical study, and Service quality.

\section{INTRODUCTION:}

At present, the world marketplace is service-based. Bangladesh also has become a service-oriented economy. In 2020, the Bangladesh Service sector's contribution was $51.30 \%$ in total Gross Domestic Product (GDP), and 39\% of totalemployed people in Bangladesh engaged in the service sector (Bangladesh Economic Review, Dhaka, 2020). Over the last 10 years, Bangladesh's urban areas population grew by $38 \%$, and only $10 \%$ growth in rural areas (Bangladesh Bureau of Statistic, Dhaka, 2001).The restaurant industry has become one of the most lucrative industries for making a profit in the world. International and local restaurant connections are satisfying the requirement of custo-

UniversePG I www.universepg.com mers in a variety of assortment of products and services.(Sabir et al., 2014).

There are a few restaurant-goers to consume domestic foods. Most of the people in our country occasionally go to the restaurant to enjoy ethnic and some western cuisine items. Unhygienic environments, poor food quality, inadequate structural facilities, scarcity of convenient food items, uneducated chefs, amateur waiters, and an inefficient management system make people unwilling to consume foods from a restaurant in our country. Although, very recently restaurant-goers have been raised in the urban areas in Bangladesh because the Bangladeshi style of life has changed. As the proportion of married women in the workforce has been 
increased, resulting in women becoming a shorter time to plan and serve meals at home. Today, meals are likewise a reconsideration rather than a prepared occasion. People themselves are hungry beside no time to cook; consequently, they eat out. The effect is the growing demand for food services of the restaurant in Bangladesh. Notwithstanding the increasing interest in this area, there is very little analysis of buyer satisfaction of food and service in our indigenous restaurant. Expanded expectations and growing culinary snacks of consumers make the restaurant business in Bangladesh.

In today's competing market services inside the same industries have increased and due to this cause services industries change the delivery of the services and products create positioning in the various communication channels (Wallin Andreassen, 1998). The principal objective of this study is to analyze the different determinants which influence customer satisfaction or which can improve customer satisfaction, such as product and service attribute, pricing policy, waiters' performance, space, etc. Though huge demand for buyer satisfaction in the food and restaurant industry, very little research is conducted in this field. This paper will explore the key service character of the restaurant in the Rangpur region andexamine the influences of restaurants' service quality on buyer satisfaction.

\section{Objectives}

The study intends to achieve the following objectives:

1) To know and examine the determinants of customer satisfaction.

2) To ascertain the causes of customer reliability.

3) To provide some recommendations to improve the service excellence of the restaurant.

\section{Literature Review}

Customer satisfaction can be explained in words of meeting the expectations of the buyers in light of parameters connected by satisfaction (Malik and Ghaffor, 2012). According to Johan; customer perception is a complicated set of thoughts and ideas and cannot be fully anticipated by a human being. (Hennig-Thurau \& Klee, 1997) got Buyer satisfaction with the goods and services of the company being the vital determinant for contentious advantage. In the light of relationship marketing, customer satisfaction is the way that manages long-term customer retention because unsatisfied customers have a very high switching rate (Lin \& Wu, 2011).

According to Zairi, (2000) the perception of the fulfillment of inner motives is called satisfaction. Consumer satisfaction has a direct influence on consumer loyalty (Mittal, 1998). If the goods or service fulfills the wants and demands of the consumer he will become satisfied and will be transformed into a loyal customer and hence will add in customer equity of the company. The company's profitability is not just described in its balance sheet but it is also estimated on basis of its reliable customer base and lifetime advantage that customers address to the company. (Oliver, 1993) recommends in his thought about consumer satisfaction is the essential philosophy of marketing strategy of any organization and plays a key role in organizational success. Customer satisfaction is the essential principle of the modern tool of CRM being used by marketers to bring and maintain customers. "Satisfaction can be viewed as a wide principle; maintain good quality is an element of satisfaction" (Zeithaml \& Bitner, 2003). Client satisfaction is normally determined through Oliver's, (1997) positions: that it's this consumer's satisfaction result. It's a ruling that a products or services characteristic, or this product or service per se, begins with a pleasurable level of intake linked satisfaction. In other words, it does not take a total level of wellbeing that has a service /product awareness.

There is a passionate relationship between fulfillment and also commitment. (Szymanski \& Henard, 2001), inside their meta-analysis, expose 15 definite and also significant relationships between 2 constructs. Bearden and Teel, (1983) in addition have conferred a new passionate association between fulfillment and also commitment. Ayse's, (2007) Prime position includes 2 main determinants: (1) the merchandise satisfies wants or alike; (2) encompassing that levels it truly is free from insufficiencies (Juran, 1988). Service is a kind of accomplishment that's offered by 1 become mutually to an option and within corporeality can be an ought to part of it (Kotler \& Keller, 2006). Through supported the obligation correlated with processes connected with program accomplished quite a few specialists 
most usually make use of program best to determine consumer fulfillment (Parasuraman et al., 1985). Service excellence is not an easy job to quantify and is estimated because this is not a product to quantify but this is the customer's perception evaluation and prejudiced opinion about something (George \& Jones, 1991). Takeuchi, (1983) quality is such an essential component or feature of something that makes some differentiation in your product and attains you remarkably in the name of contentious choice. Service position is assessed when the user of service relates his thought with experience. Gronroos, (1984) Consumer satisfaction is a wide thought and is affected by many determinants and service excellence is the main determinant of customer fulfillment (Zeithaml \& Bitne, 2006). (Bitner \& Hubbert, 1994) provide two advantages of describing the phenomena: consumer fulfillment as a result of some special adventure or event mixed outcome of satisfaction.

SERVQUAL product provides an advantageous way to be correlated with estimating program excellent designed by PZB within 1988, as described by this product customers' perception and also promises to start upon all 5 dimensions: tangibles (Actual conditions or smooth design), authenticity (Product quality), responsiveness (Service feature), promise and also encouragement. Arranged by perspectives correlated with SERVQUAL product same conclusions are already put on the restaurant industry through (Stevens, et al., 1995) and also he or she provided DINESERV from SERVQUAL. Inside the restaurant business, only a part of planning can be a performance and it's also intangible and also contemporaries and also utilization of commodities have enhanced significantly within the close-up association. Furthermore, customers prefer broad variety and also self-collection plus they assess one's giving along with some others when those customers have got clusters correlated with eating positions inside their feelings because of connecting point partners (Neal, 1999). In various organization business, we will create all 5 most critical dimensions which make a very good organization and also these commonly program unique, appreciable, trustworthyness, responsiveness assurance, etc. (Azadavar et al., 2011; Satya, 2011) recognized corporations must keep their distinction in quality mainly because everyone is a lot more attentive to quality excellence as contrasted to price. Consumers someday buy more reliable brands in light of quality instead of considering the price argument (Aktar, 2021; Rajput et al., 2012).

Tsiotsou, (2006) recognized a good primary impact correlated with the perceived quality upon acquiring intentions. people respond areas along with two general, and also opposed, kinds of operations: strategy or even stopping (Mehrabian \& Russell, 1974). It is informed of which besides the actual physical system of the organization inviting or even preventing collection, the actual physical arrangement of the organization can also determine the amount correlated with fulfillment consumers attain after within (Darley \& Gilbert, 1985). This includes research about the "ambiance" (Bitner, 1992)which is an "artificial environment" and also how it affects both clients and also workers within the application method. Skindaras, (2009) we can find a lot of merchandise on this planet occupying different price varieties. Price is the element of the four P's of Marketing Mix that has an important role in the fulfillment of the marketing approach (Kotler \& Armstrong, 2016). (Han \& Ryu, 2009) claims that one of the most versatile determinants which developed immediately is the pricing (Andaleeb \& Conway, 2006) the costs connected with restaurant merchandise moreover vary according to the style of restaurant. If your price is high, clients may very well demand premium quality. "Also, in the situation the price is insignificant, clients may maybe believe that restaurant is poor in names of merchandise and also program unique. Moreover, due to the competition within the restaurant business, clients will recognize interior reference point price scales inside their head plus they steadily assess and also examine the benefits in terms of many features associated with restaurant upon every obtain, an inside reference point price is perceived an assessment within latent buyers 'memory of which acts as criteria proposed for distinguishing definite price ranges (Grewal et al., 1998). Nezakati, Kuan, and Asgari, (2011) suggested product quality, customer fulfillment, and brand liability as the prevailing variable that prompts customer loyalty to fancied fast-food restaurants. Research conducted out by Tat et al. (2011) to examine Consumers' Purchase Purposes in Fast Food Business on Undergraduate 
Students practicing the five elements of service excellence, a promise was pronounced to be the most potent determinant of customer fulfillment towards fast-food restaurants (FFRs), followed by responsiveness, loyalty, tangibility, and compassion. The outcomes also confirmed the assertion that customer satisfaction can drive customer purchase purposes. In the study conducted by Ergin and Akbay(n.d), brand name prominence, cost, adaptability, compatibility, and quality were recognized as authoritative determinants that affect young consumers' choices of various brands of fast food Business. It was also recognized that these five determinants are significantly associated with various demographic determinants like age, gender, and income level.

\section{RESULTS AND DISCUSSION:}

Table 1: Customer's Perception of Restaurant Image (Source: Field Study).

\begin{tabular}{|c|c|c|c|c|c|}
\hline Factors & Strongly Satisfied & Satisfied & Neutral & Dissatisfied & Strongly Dissatisfied \\
\hline $\begin{array}{l}\text { I regularly suggest this restaurant as a prime } \\
\text { selection contrasted to other restaurants. }\end{array}$ & 42 & 29 & 10 & 14 & 25 \\
\hline I would suggest the restaurant to others. & 29 & 25 & 5 & 40 & 31 \\
\hline $\begin{array}{l}\text { I would not change to different } \\
\text { Restaurant next time. }\end{array}$ & 12 & 13 & 16 & 27 & 52 \\
\hline
\end{tabular}

The positive perception of the buyer has a convincing relationship with the selection of the restaurant as a prime selection compared to another restaurant, the reference to others, and change to a different restaurant next time. Table 1 displays that $35 \%$ of respondents prefer the restaurant as a prime selection because of the positive perception of the restaurant but $36 \%$ of respondents do not prefer the restaurant as a prime selection because of the positive perception for the restaurant, $24 \%$ of respondents suggest another who

\section{METHODOLOGY:}

This was anexperiential study that was mainly based on primary data. Data were collected from the restaurant-goers of Rangpur city. This study had been conducted from mid-2019 to December 2020. Respondents were selected randomly from the customers of the restaurant. The researcher reached with 120 customers' face-to-face interaction.

A structural questionnaire was outlined by applying 5 points Likert scale questionnaire that was prepared to range from Strongly Satisfied, Satisfied, Impartial, and Dissatisfied to Strongly Dissatisfied. An open-ended question was also asked to identify the overall perception of the customers. Besides, secondary sources, like - books, thesis, journals were examined to assess past researchers escorted on consumer satisfaction in the restaurant market.

Table 2: Products and Services Quality (Source: Field Study).

\begin{tabular}{|c|c|c|c|c|c|}
\hline Factors & $\begin{array}{c}\text { Strongly } \\
\text { Satisfied }\end{array}$ & Satisfied & Neutral & Dissatisfied & $\begin{array}{c}\text { Strongly } \\
\text { Dissatisfied }\end{array}$ \\
\hline Foods are served as per the order of customers. & 15 & 17 & 8 & 56 & 24 \\
\hline $\begin{array}{c}\text { Employees have the devotion to maintaining } \\
\text { quick and quality service. }\end{array}$ & 14 & 16 & 6 & 63 & 21 \\
\hline
\end{tabular}

Goods and service quality affects the customer's satisfaction. Subserving requested food timely \& accurately and the devotion of the employees to manage quick and quality services are considered to acknowledge the products and services quality properly. The products has an assertive perception in the market but $25 \%$ of respondents do not suggest others who have no positive perception in the market, only $10 \%$ respondents will not change to the different restaurant next time but $43 \%$ of customers will switch to another restaurant in next time. It has been noticed that the positive perception of the consumers is extremely needed to address the restaurant a prime selection and suggest to others as well as not to change to another restaurant. and services quality depends on the Serving placed in food time \& accurately and the devotion of the employee to manage quick and quality service. Table 2 represents that $12 \%$ of respondents of the study regions are accepted that the restaurant's employees 
assist ordered food at the right time but more than $47 \%$ of respondents of the study regions are not accepted that the restaurant's employees assist ordered food at the right time, only $13 \%$ of respondents of the study regions are accepted that the employees are devoted to serving quick and quality service but $53 \%$ of respondents of the study regions are not agreed that the employees are devoted to serving quick and quality service.

Table 3: Price Integrity (Source: Field Study).

\begin{tabular}{|c|c|c|c|c|c|}
\hline Factors & $\begin{array}{c}\text { Strongly } \\
\text { Satisfied }\end{array}$ & Satisfied & Neutral & Dissatisfied & $\begin{array}{c}\text { Strongly } \\
\text { Dissatisfied }\end{array}$ \\
\hline Products and services price as per cost. & 11 & 25 & 9 & 62 & 13 \\
\hline $\begin{array}{c}\text { The deliciousness of food items is appropriate } \\
\text { compared with the price. }\end{array}$ & 12 & 26 & 13 & 58 & 11 \\
\hline The price is equal for all customers. & 10 & 24 & 7 & 55 & 24 \\
\hline The price is comparatively cheap to others. & 13 & 26 & 9 & 55 & 17 \\
\hline
\end{tabular}

Table 3 presents the respondents' overall feelings regarding the price integrity of the restaurant in the study regions. The analysis found that $22 \%$ of respondents are accepted regarding the food item's price relatively cheaper, $20 \%$ of respondents are accepted to approach the restaurant equally with food item's price, only $21 \%$ of respondents are thinking the price is based on cost and $22 \%$ of respondents accepted that the deliciousness of food items is contrasted with the price. The pleasure of the customers depends on the price fairness in a restaurant. Therefore, few consumers are recognized positively about the considered determinants. So, there is a possibility to modify the price in a restaurant of the study areas.

The customers usually go to the restaurant depends on their loyalty. The Table 4 shows that more than 16\% of respondents regularly visit the restaurant but $50 \%$ of respondents do not usually visit the restaurant, $13 \%$ of respondents have the intention to revisit the restaurant but $47 \%$ of respondents have no plan to visit the restaurant. the Customer loyalty of the restaurant service has no connection with the regular visit to the restaurant and intention to revisit the restaurant.

Table 4: Customer Loyalty (Source: Field Study).

\begin{tabular}{|c|c|c|c|c|c|}
\hline Factors & $\begin{array}{c}\text { Strongly } \\
\text { Satisfied }\end{array}$ & Satisfied & Neutral & Dissatisfied & $\begin{array}{c}\text { Strongly } \\
\text { Dissatisfied }\end{array}$ \\
\hline I always visit the restaurant. & 11 & 19 & 8 & 60 & 22 \\
\hline I assign to revisit the restaurant. & 12 & 16 & 7 & 56 & 29 \\
\hline
\end{tabular}

Table 5: Comfort with the Environmental Factors of the Restaurant (Source: Field Study).

\begin{tabular}{|c|c|c|c|c|c|}
\hline Factors & $\begin{array}{c}\text { Strongly } \\
\text { Satisfied }\end{array}$ & Satisfied & Neutral & Dissatisfied & $\begin{array}{c}\text { Strongly } \\
\text { Dissatisfied }\end{array}$ \\
\hline The area is wide enough. & 22 & 50 & 11 & 26 & 11 \\
\hline It has an adequate lighting facility and air conditioning. & 19 & 52 & 10 & 25 & 14 \\
\hline It keeps a suitable sound system. & 24 & 59 & 9 & 23 & 5 \\
\hline
\end{tabular}

Buyer satisfaction and employee's working satisfaction depend on the environmental factors of the restaurant. In this analysis, the researchers took into consideration the three factors as a restaurant environment such as area wideness, sound level, lighting facility \& air conditioning.

Table 5 represents that $42 \%$ of respon-dents have accepted concerning the area wideness and $22 \%$ of respondents are not accepted concerning the wideness of the area, $49 \%$ of customers are accepted concerning the suitable sound system and 19\% of customers are not accepted concerning the proper sound practice of the restaurant, $43 \%$ of respondents are accepted concerning the adequate lighting amenity and air conditioning of the restaurant and $21 \%$ res-pondents are not accepted concerning the adequate lighting amenity and air conditioning of the restaurant. 
Table 6: Comfort with the Staffs' Service (Source: Field Study).

\begin{tabular}{|c|c|c|c|c|c|}
\hline Determinants & $\begin{array}{l}\text { Strongly } \\
\text { Satisfied }\end{array}$ & Satisfied & Neutral & Dissatisfied & $\begin{array}{c}\text { Strongly } \\
\text { Dissatisfied }\end{array}$ \\
\hline The Staffs serve food in the assured time. & 20 & 46 & 8 & 30 & 16 \\
\hline The Staffs immediately manages the complaint. & 26 & 52 & 10 & 25 & 7 \\
\hline The Staffs are well dressed. & 34 & 44 & 11 & 25 & 6 \\
\hline The Staffs are aware of the menu. & 22 & 52 & 13 & 24 & 9 \\
\hline
\end{tabular}

A regular visit to the same restaurant depends on the pleasure of the staff's service. The Table 6 represents that in assured time, only $38 \%$ of respondents are accepted regarding the supplied food and more than $25 \%$ of respondents were not accepted regarding the supplied food in the assured time, about $43 \%$ of respondents are accepted regarding the quick improvement of misconceptions of the staffs and more than $21 \%$ customers were not accepted regarding the quick improvement of misconceptions of the staffs, $37 \%$ customers were satisfied by the staffs dressed up and, $21 \%$ customers were not satisfied by the staff dressed up, $46 \%$ of customers assumed that the staffs are

Table 7: The Reputation of the Restaurant (Source: Field Study).

\begin{tabular}{|c|c|c|c|c|c|}
\hline Determinants & Strongly Satisfied & Satisfied & Neutral & Dissatisfied & Strongly Dissatisfied \\
\hline $\begin{array}{c}\text { I customarily practice this restaurant as my } \\
\text { prime choice related to other restaurants. }\end{array}$ & 11 & 14 & 11 & 62 & 22 \\
\hline I would suggest the restaurant to others. & 10 & 17 & 14 & 61 & 18 \\
\hline
\end{tabular}

Table 8: The Overall Satisfaction of the Restaurant (Source: Field Study).

\begin{tabular}{|c|c|c|c|c|c|}
\hline Determinants & Strongly Satisfied & Satisfied & Neutral & Dissatisfied & Strongly Dissatisfied \\
\hline I am pleased by the overall service. & 13 & 29 & 7 & 46 & 25 \\
\hline No cause to complain. & 10 & 25 & 11 & 50 & 24 \\
\hline
\end{tabular}

The researcher finds that only $24 \%$ of respondents of the restaurant of Rangpur City are agreed concerning the pleasure of the all services \& environment of the restaurant. Again more than $21 \%$ of respondents have a complaint to the restaurant of Rangpur City.

\section{FINDINGS AND RECOMMENDATIONS:}

1) The judgment of the customer of the restaurant depends on the positive reflection of the restaurant. The research finds that an average of $36 \%$ of customersis strongly disagreed about the positive thought of the restaurant. So, the administration of the restaurant in the Rangpur City Area should take necessary action to increase positive image.

2) Products and services quality is most important for satisfaction, an average of $60 \%$ of customers are dissatisfied withproducts and services quality

UniversePG I www.universepg.com aware of the food menu but more than $20 \%$ respondents do not believe that the staffs are well-informed regarding the food menu.

Reputation has a magnificent impact on customers to revisit the restaurant. The researcher finds that only $12 \%$ of respondents are recognized to practice the restaurant as their prime choice related to other restaurants and $52 \%$ of respondents are not recognized that, $14 \%$ of respondents are allowed to suggest this restaurant to another and $51 \%$ of respondents are notallowed that (Table 7). 
7) About $52 \%$ of customers believe that most utmost of the restaurants in Rangpur City is not well-reputed. So Authority should concern about their restaurant reputation.

8) Overall restaurant services in Rangpur City Area are not so satisfactory. The research shows that about $27 \%$ of customers are pleased and about $48 \%$ of customers are unsatisfied withthe overall restaurant service.

\section{CONCLUSION:}

The prime focus of this research was to measure the customer satisfaction level of the restaurant industry. Based on this analysis restaurants should improve products and services attributes, price should be fair with the food status, restaurants should be more cautious concerning its reliability and of course, try to give more concentration to customer acknowledgment. Regarding the space availability and waiters service customers presented a positive review, necessary actions must be taken to keep it up. Achievable, this research will assist the researchers to find out the main factors of customers satisfaction in the Rangpur City area. Finally \& most importantly this researcher recommends that The administrations and respective authorities should improve the overall services of the restaurant industry in the Rangpur City area.

\section{ACKNOWLEDGEMENT:}

We would like to thank the people who have helped and cooperated at the time of the field survey. We do sincerely admire and gratefully acknowledged the support \& of assistance of the most respectable Mr. Md. Ekhlas Uddin, Gono Bishwabidyalay and also thanks to the organizations for support to successfully complete the present research study.

\section{CONFLICTS OF INTEREST:}

The authors declare that there are no conflicts of interest to publish it.

\section{REFERENCES:}

1) Aktar MS. (2021). Determinates service quality and its effect on patients' satisfaction of private medical college hospitals, Rangpur, Bangladesh, Int. J. Manag. Account. 3(4), 91-105. https://doi.org/10.34104/ijma.021.0910105

2) Andaleeb, S. S. \& Conway, C. (2006). Customer satisfaction in the restaurant industry: an UniversePG I www.universepg.com examination of the transactions specific model. Journal of Services Marketing, 20(1), pp. 3-11.

3) Bitner, M. J. (1992). Servicescapes: The Im-pact of Physical Surroundings on Customers and Employees. Journal of Marketing, 56, pp. 57-71. https://journals.sagepub.com/doi/10.1177/0022242 $\underline{99205600205}$

4) Bitner, M. J. \& Hubbert, A. R. (1994). Encounter Satisfaction versus Overall Satis-faction versus Quality: The Customer's Voice. In: Service Quality: New Directions in Theory and Practice. s.1.: Sage, Thousand Oaks, CA, pp. 76-77. https://sk.sagepub.com/books/service-quality/n3.xml

5) Darley, J. M. \& T.Gilbert, D. (1985). Social Psychological Aspects of Environmental Psychology. In: Handbook of Social Psychology (3rd Edit.). G. Lindzey and E. Aronson (eds) ed. New York, NY: Random House, Inc., 949-991. https://www.semanticscholar.org/paper/Social-Psy chological-Aspects-of-Environmental-by-M.-Ellis/ d3e226cad465d4e0b5d14306da4221a8c85d5827

6) Han, H. \& Ryu, K. (2009). The Roles of the Physical Environment, Price Perception, and Customer Satisfaction in Determining Custo-mer Loyalty in the Restaurant Industry. J. of Hospitality \& Tourism Research, 33(4), pp. 487-510. https://doi.org/10.1177/1096348009344212

7) Hennig-Thurau, T. \& Klee, A. (1997). The impact of customer satisfaction and relation-ship quality on customer retention: A critical reassessment and model development. Psychology \& Marketing, 14(8), pp. 737-764.

https://onlinelibrary.wiley.com/doi/abs/10.1002/(SI CI)1520-6793(199712)14:8\%3C737::AID-MAR2\% 3E3.0.CO;2-F

8) Kotler, P. \& Armstrong, G. (2016). Principles of Marketing. $15^{\text {th }}$ ed. New Jersey:: Prentice-Hall.

9) Mehrabian, A. \& Russell, J. A. (1974). An Approach to Environmental Psychology.

https://mitpress.mit.edu/books/approach-environm ental-psychology

10) Mittal, B. (1998). Retrospective: why do customers switch? The dynamics of satisfaction versus loyalty. Journal of Services Marketing, 30(6), pp. 569-575.

https://www.emerald.com/insight/content/doi/10.1 108/JSM-07-2016-0277/full/html 
11) Neal, W. D. (1999). Satisfaction Is Nice, But Value Drives Loyalty. Marketing Research, 11 (1), pp. 20-23.

https://www.scribd.com/document/457387287/Sati sfaction-is-Nice-But-Value-Drives-Loyalty

12) Oliver, R. L. (1993). A conceptual model of service quality and service satisfaction: Compatible goals and different concepts, In Swart TA, Bowen DE, Brown SW. (eds.). Advances in Service Marketing and Management.

13) Parasuraman, A. P., Zeithaml, V. A. \& Berry, L. L. (1985). A Conceptual Model of Service Quality and Its Implications for Future Research. Journal of Marketing, 49, pp. 41-50. https://doi.org/10.1177/002224298504900403

14) Satya, S. (2011). Retailer's perspective on support services offered by vembanad white cement. Journal of Economics and Behavioral Studies, 5(2), pp. 186-190.

https://www.semanticscholar.org/paper/Retailer\%2 7s-Perspective-on-Support-Services-Offered-Saty a/c5a81626722a3307c430058d5c4b8f809c73c61a
15) Stevens, P., Knutson, B. \& Patton, M. (1995). Dineserv: A Tool for Measuring Service Quality in Restaurants. Cornell Hotel \& Restaurant Administration Quarterly, 36(2), pp. 56-60. https://journals.sagepub.com/doi/10.1177/0010880 49503600226

16) Szymanski, D. M. \& Henard, D. H. (2001). Customer Satisfaction: A Meta-Analysis of the Empirical Evidence. Journal of the Academy of Marketing Science, 29(1), pp. 16-35. https://doi.org/10.1177/00920703010290010

17) Tsiotsou, R. H. (2006). The role of perceived product quality and overall satisfaction on purchase intentions. International Journal of Consumer Studies., 30(2), pp. 207-217. https://doi.org/10.1111/j.1470-6431.2005.00477.x

18) Zeithaml, V. \& Bitne, M. J. (2006). In: Services Marketing. $4^{\text {th }}$ ed. s.1.: Richard D. Irwin, Inc., p. 85.

https://www.textbooks.com/Services-Marketing-4 ${ }^{\text {th }}$ -Edition/9780072961942/Valarie-Zeithaml-Mary-J o-Bitner-and-Dwayne-D-Gremler.php

\section{APPENDIX:}

\section{Demographic Configuration}

\begin{tabular}{|c|c|c|}
\hline Demography & Number & Sample\% \\
\hline \multicolumn{3}{|c|}{ Gender } \\
\hline Male & 85 & $70.83 \%$ \\
\hline Female & 35 & $29.17 \%$ \\
\hline \multicolumn{3}{|c|}{ Age } \\
\hline$>15$ years & 6 & $5 \%$ \\
\hline $15>40$ years & 88 & $73.33 \%$ \\
\hline$<40$ years & 26 & $21.77 \%$ \\
\hline \multicolumn{3}{|c|}{ Income } \\
\hline$>15,000.00$ & 43 & $35.83 \%$ \\
\hline $15,000.00>40,000.00$ & 66 & $55 \%$ \\
\hline$<40,000.00$ & 11 & $9.17 \%$ \\
\hline \multicolumn{3}{|c|}{ Occupation } \\
\hline Students & 56 & $46.67 \%$ \\
\hline Businessmen & 38 & $31.67 \%$ \\
\hline Teachers & 15 & $12.50 \%$ \\
\hline Others & 11 & $9.16 \%$ \\
\hline
\end{tabular}

Citation: Arefin MS., and Hossain MR. (2021). Customer satisfaction analysis of restaurant industry: an empirical study on Rangpur city, Int. J. Manag. Account. 3(5), 106-113.

https://doi.org/10.34104/ijma.021.01060113@店 